\title{
Validated HPTLC and Stability Indicating RP-HPLC Methods for the Simultaneous Estimation of Moxifloxacin and Dexamethasone in Bulk and Ophthalmic Dosage Form
}

\author{
B. MOHAN GANDHI ${ }^{1}$, A. LAKSHMANA RAO ${ }^{2 *}$ and J. VENKATESWARA RAO ${ }^{3}$
}

${ }^{1}$ Sri Vasavi Institute of Pharmaceutical Sciences, Tadepalligudem - 534101, India.

${ }^{2}$ V.V. Institute of Pharmaceutical Sciences, Gudlavalleru - 521356, India.

${ }^{3}$ Bharat School of Pharmacy, Mangalpalli - 501510, India.

*Corresponding author E-mail: dralrao@gmail.com

http://dx.doi.org/10.13005/ojc/320433

(Received: February 12, 2016; Accepted: July 15, 2016)

\begin{abstract}
Novel HPTLC and stability indicating RP-HPLC methods were developed for simultaneous estimation of Moxifloxacin (MOX) and Dexamethasone (DEX) in ophthalmic dosage form. For HPTLC method, the separation was carried out on HPTLC aluminum plates using acetonitrile:water:ammonia (8:1:0.5 V/V/V) as mobile phase and developed plates were read at $266 \mathrm{~nm}$. The drugs were resolved satisfactorily with $R_{f}$ values of $0.09 \pm 0.01$ and $0.74 \pm 0.01$ for MOX and DEX, respectively. The RPHPLC analysis is carried out on Shiseido C18 column ( $250 \mathrm{~mm} \times 4.6 \mathrm{~mm}$ I.D., $5 \mu \mathrm{m})$, using 0.02M acetate buffer ( $\mathrm{pH}$ is 4 adjusted with triethylamine) and acetonitrile in the ratio of $60: 40 \mathrm{~V} / \mathrm{V}$ with a flow rate of $1.2 \mathrm{~m} / \mathrm{min}$ and the detection was carried out at $254 \mathrm{~nm}$. The retention times were found to be $2.144 \pm 0.5 \mathrm{~min}$ and $4.732 \pm 0.5 \mathrm{~min}$. for MOX and DEX respectively. Developed methods were validated as per $\mathrm{ICH}$ guidelines and were found to be within the limits.
\end{abstract}

Keywords: Moxifloxacin, Dexamethasone, HPTLC, RP-HPLC, Validation.

\section{INTRODUCTION}

Moxifloxacin (Fig. 1) is chemically 7-[(4aS,7aS)-octahydro-1H-pyrrolo[3,4-b]pyridin6-yl]-1-cyclopropyl-6-fluoro-8-methoxy-4-oxo-1,4dihydroquinoline-3-carboxylic acid. The bactericidal action of MOX results from inhibition of the enzymes topoisomerase II (DNA gyrase) and topoisomerase IV. DNA gyrase is an essential enzyme that is involved in the replication, transcription and repair of bacterial DNA. Topoisomerase IV is an enzyme known to play a key role in the partitioning of the chromosomal DNA during bacterial cell division'.

Dexamethasone (Fig. 2) is chemically 9-fluoro-11 $\alpha, 17,21$-trihydroxy-16 $\alpha$-methylpregna1,4-diene,3,20-dione. The antiinflammatory actions of DEX are thought to involve phospholipase $A_{2}$ 
inhibitory proteins, lipocortins, which control the biosynthesis of potent mediators of inflammation such as prostaglandins and leukotrienes ${ }^{2,3}$.

Literature survey reveals that few analytical methods including UV ${ }^{4-8}, \mathrm{HPLC}^{9-16}$ and HPTLC ${ }^{17-19}$ methods are available for the estimation of MOX and DEX individually and in combination with other drugs. No HPTLC and stability indicating RPHPLC methods are available for the simultaneous estimation of MOX and DEX. Hence, we made an attempt to develop simple HPTLC and RP-HPLC methods for the estimation of these drugs. Similarly, to establish stability indicating nature of the RP-HPLC method, forced degradation of drug substances was performed under stress conditions (peroxide, acid, base, thermal, UV and neutral hydrolysis). The proposed methods were optimized and validated as per the International Conference on Harmonization $(\mathrm{ICH})$ guidelines ${ }^{20,21}$.

\section{MATERIALS AND METHODS}

\section{Chemicals and reagents}

MOX and DEX working standards were procured from Yarrow Chemicals Ltd., Mumbai. Commercially available Moxi Mep D eye drops were purchased from the local pharmacy. HPLC grade acetonitrile and methanol were purchased from Merck specialities Pvt. Ltd., Mumbai. HPLC grade water was purchased from Thermo Fisher Scientifics Ltd., Mumbai. Ammonia solution, concentrated hydrochloric acid AR grade, triethylamine, sodium hydroxide pellets purified and hydrogen peroxide $30 \%$ AR grade were procured from Merck specialties Pvt. Ltd., Mumbai.

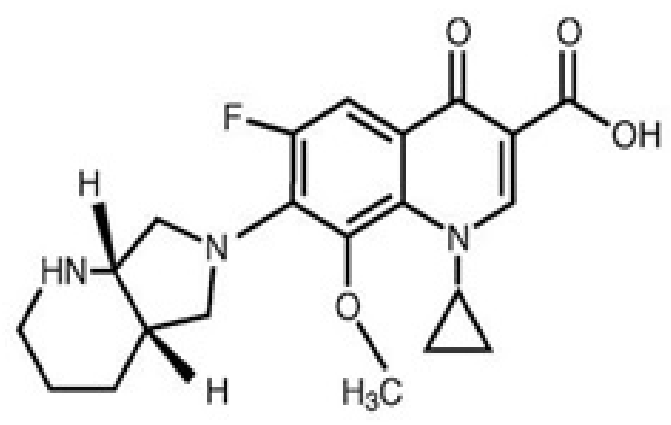

Fig. 1: Structure of Moxifloxacin

\section{Instrumentation and analytical conditions HPTLC}

HPTLC method was performed using silica gel $60 \mathrm{~F}_{254}$ precoated aluminum plates with thickness $2 \mathrm{~mm}$, E-Merck, Germany as a stationary phase. The instrument used was CAMAG-HPTLC system comprising of CAMAG LINOMAT-V automatic sample applicator, CAMAG TLC SCANNER with CAT S planner software, CAMAG-UV cabinet and CAMAG twin trough glass chamber with stainless steel lids. The source of radiation was deuterium lamp emitting a continuous UV spectrum between $190-400 \mathrm{~nm}$. The samples were spotted in the form of bands of width 8 $\mathrm{mm}$ with a Camag $100 \mu \mathrm{l}$ sample syringe (Hamilton, Switzerland). A constant application rate of $0.1 \mu \mathrm{l} / \mathrm{sec}$ was used with the space between the bands as 14.5 $\mathrm{mm}$. The slit dimension was kept at $6.00 \times 0.45 \mathrm{~mm}$ and scanning speed was $20 \mathrm{~mm} / \mathrm{sec}$.

\section{HPLC}

RP-HPLC method was performed on HPLC system (Shimadzu) consisting of binary gradient pump and UV detector (LC-20AD) was employed for analysis. Chromatographic data was acquired using Lab solutions software. Shiseido C18 column (250 $\mathrm{mm} \times 4.6 \mathrm{~mm}$ I.D., $5 \mu \mathrm{m}$ ) was used as stationary phase.

\section{Optimized chromatographic conditions}

Initially different combinations of mobile phases were tried and finally obtained better separation with the mentioned mobile phase combination.

\section{HPTLC}

TLC aluminium foiled plates precoated with silica get $60 \mathrm{~F}_{254}$ with thickness of $2 \mathrm{~mm}$ were used<smiles>C[C@H]1C[C@H]2[C@@H]3CCC4=CC(=O)C=C[C@]4(C)[C@@]3(F)[C@@H](O)C[C@]2(C)[C@]1(O)C(=O)CO</smiles>

Fig. 2: Structure of Dexamethasone 
as stationary phase. Acetonitrile:water:ammonia in the ratio of $8: 1: 0.5 \mathrm{~V} / \mathrm{V} / \mathrm{V}$ solution was used as a mobile phase and the chamber was saturated for $30 \mathrm{~min}$. Amount of mobile phase used was $9.5 \mathrm{ml}$ per run. Sample was applied at a constant rate of $0.1 \mu \mathrm{l} / \mathrm{sec}$ having scan speed of $20 \mathrm{~mm} / \mathrm{sec}$ with 8 $\mathrm{mm}$ band width, the samples were separated by ascending technique. The chamber was maintained at $25 \pm 0.5^{\circ} \mathrm{C}$ temperature and $50-60 \%$ relative humidity. The detection was carried out at $266 \mathrm{~nm}$. UV scan showing the overlain spectrum of two drugs is shown in Fig. 3. HPTLC chromatogram showing well resolved peaks can be seen in Fig. 4.

\section{HPLC}

The RP-HPLC analysis was carried out using Shiseido C18 column (250 mm × $4.6 \mathrm{~mm}$ I.D., $5 \mu \mathrm{m})$ as stationary phase. $0.02 \mathrm{M}$ acetate buffer $(\mathrm{pH}$ is 4 adjusted with triethylamine) and acetonitrile in the ratio of $60: 40 \mathrm{~V} / \mathrm{V}$ was used as a mobile phase. The flow rate of $1.2 \mathrm{ml} / \mathrm{min}$. was fixed and the detection was carried out at $254 \mathrm{~nm}$. The summary of system suitability parameters were shown in Table 1. HPLC chromatogram showing well resolved peaks can be seen in Fig. 5.

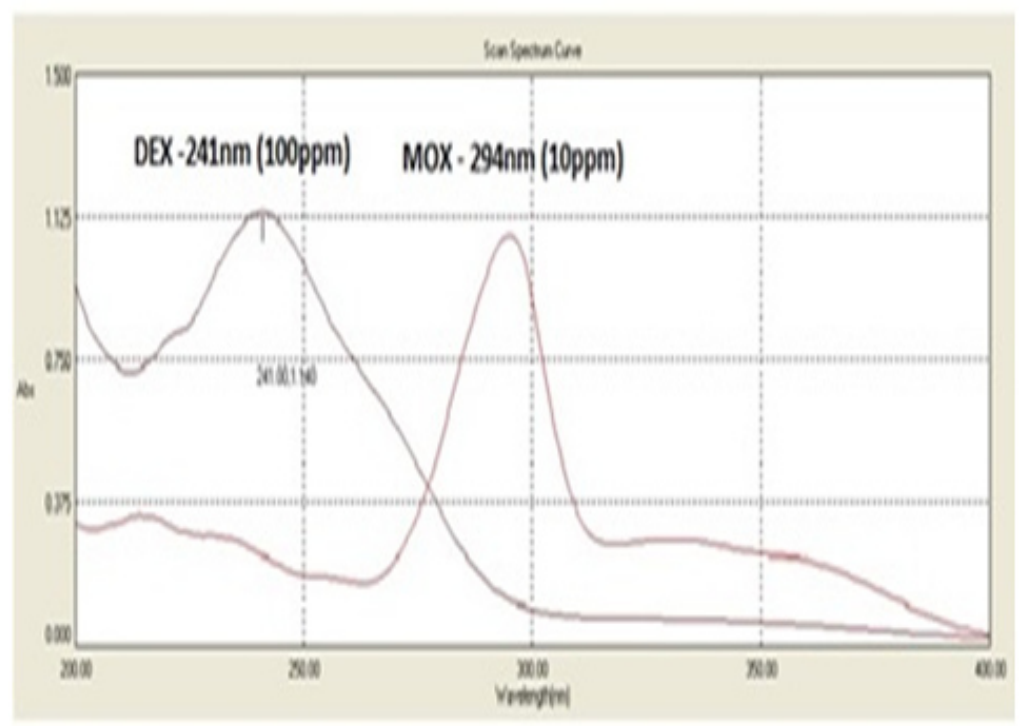

Fig. 3: UV overlapping spectrum of MOX \& DEX

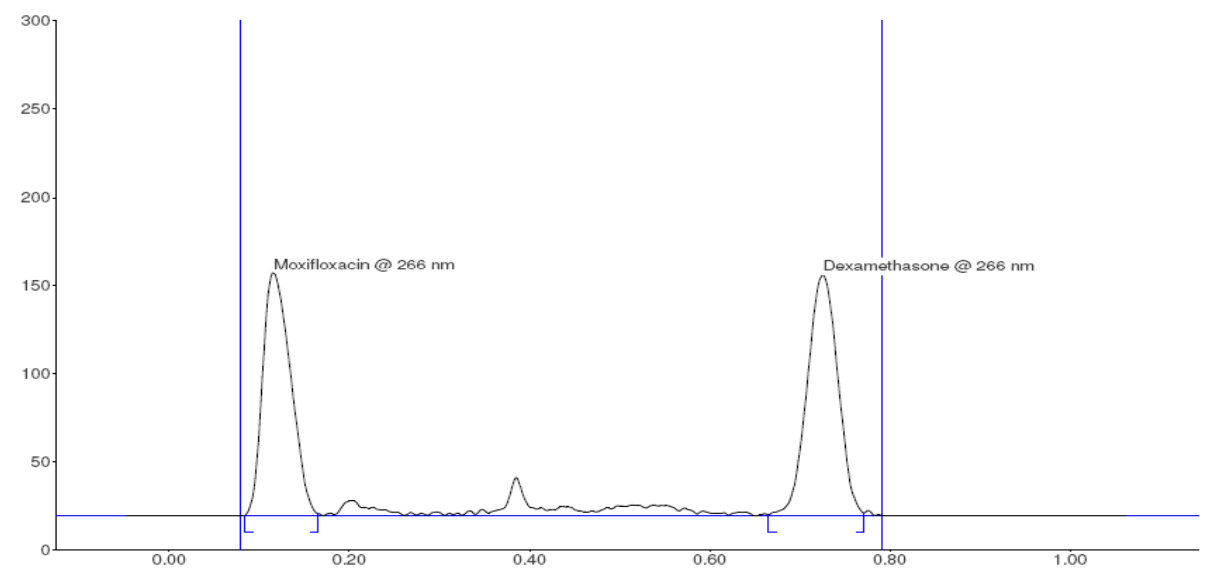

Fig. 4: HPTLC Chromatogram representing the well resolved peaks of MOX \& DEX 


\section{Preparation of solutions}

HPTLC

Preparation of MOX stock solution

MOX standard stock solution containing 100 $\mu \mathrm{g} / \mathrm{ml}$ of MOX was prepared by dissolving $10 \mathrm{mg}$ of MOX in $100 \mathrm{ml}$ volumetric flask using methanol:water (50:50 V/V) as solvent.

\section{Preparation of MOX working standard}

$3 \mathrm{ml}$ of above solution was diluted in $10 \mathrm{ml}$ methanol:water (50:50 V/V) to get final concentration of $30 \mu \mathrm{g} / \mathrm{ml}$. $10 \mu \mathrm{l}$ was applied as band which contains $0.3 \mu \mathrm{g} / \mathrm{spot}$.

\section{Preparation of DEX stock solution}

DEX standard stock solution containing $1000 \mu \mathrm{g} / \mathrm{ml}$ of DEX was prepared by dissolving $10 \mathrm{mg}$ of DEX in $10 \mathrm{ml}$ volumetric flask using methanol:water (50:50 V/V) as solvent.

\section{Preparation of DEX working standard}

$3 \mathrm{ml}$ of above solution was diluted in $10 \mathrm{ml}$ methanol:water (50:50 V/V) to get final concentration of $300 \mu \mathrm{g} / \mathrm{ml}$. $10 \mu \mathrm{l}$ was applied as band which contains $3 \mu \mathrm{g} / \mathrm{spot}$.

\section{HPLC}

\section{Preparation of MOX stock solution}

MOX standard stock solution containing $100 \mu \mathrm{g} / \mathrm{ml}$ of MOX was prepared by dissolving $10 \mathrm{mg}$ of MOX in $100 \mathrm{ml}$ volumetric flask using water:acetonitrile in the ratio of $50: 50 \mathrm{~V} / \mathrm{V}$ as solvent.

\section{Preparation of DEX stock solution}

DEX standard stock solution containing $100 \mu \mathrm{g} / \mathrm{ml}$ of DEX was prepared by dissolving $10 \mathrm{mg}$ of DEX in $100 \mathrm{ml}$ volumetric flask using water:acetonitrile in the ratio of $50: 50 \mathrm{~V} / \mathrm{V}$ as solvent.

\section{Preparation of MOX and DEX working standard mixture}

From the above solutions, standard stock solutions were prepared in $10 \mathrm{ml}$ volumetric flask and made up the volume with the mobile phase to

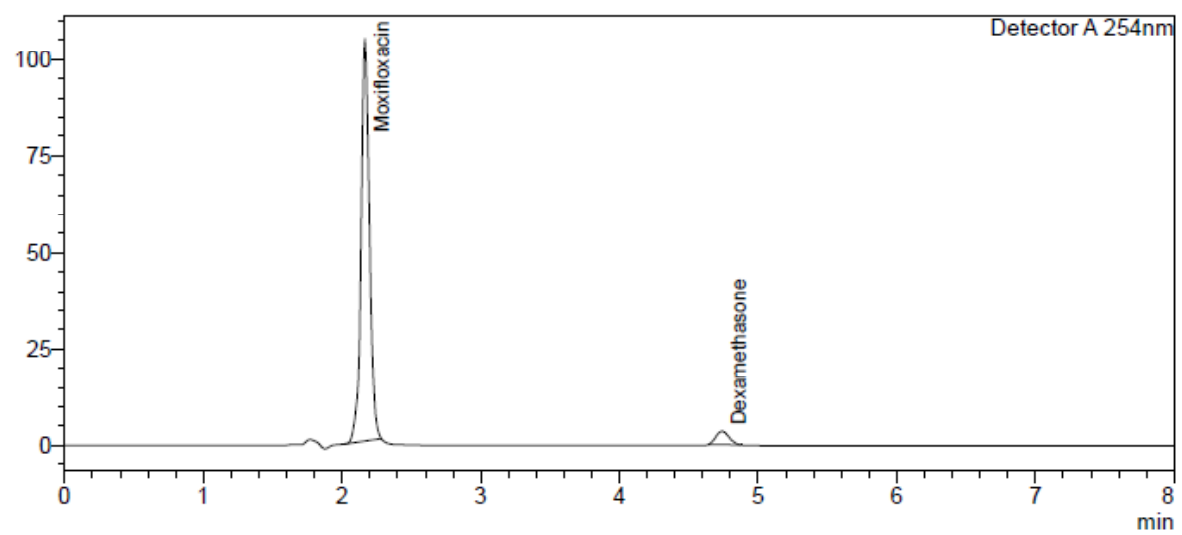

Fig. 5: RP-HPLC Chromatogram showing well resolved peaks of MOX and DEX

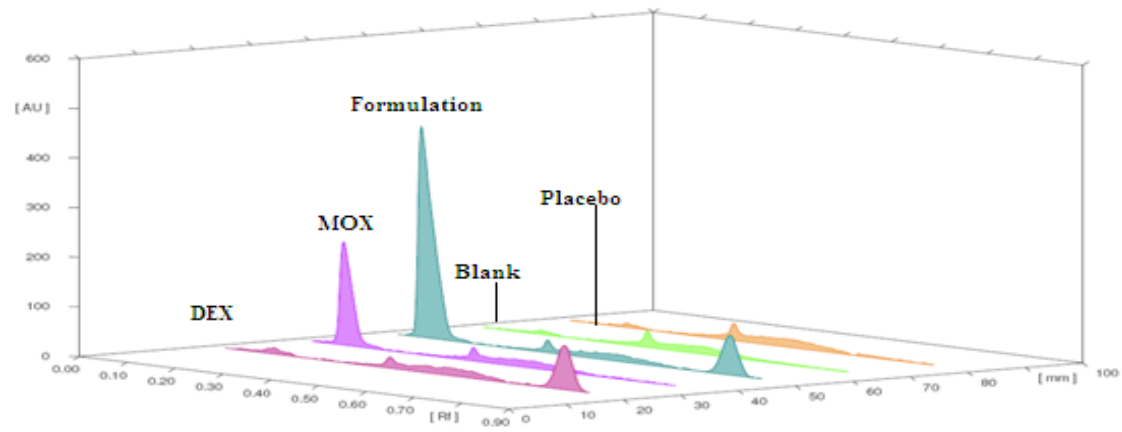

Fig. 6: Specificity Studies on HPTLC 
get the concentration of $25 \mu \mathrm{g} / \mathrm{ml}$ of MOX and $5 \mu \mathrm{g} /$ $\mathrm{ml}$ of DEX.

\section{Procedure for forced degradation study using} RP-HPLC

Degradation studies were performed in sample solutions containing $25 \mu \mathrm{g} / \mathrm{ml}$ of MOX and 5 $\mu \mathrm{g} / \mathrm{ml}$ of DEX.

\section{Acid hydrolysis}

For acid degradation, $1 \mathrm{ml}$ of $0.1 \mathrm{M}, 0.5 \mathrm{M}$, $1 \mathrm{M}$ and $2 \mathrm{M} \mathrm{HCl}$ were added individually to final drug solution in different volumetric flasks and they were refluxed for $1 \mathrm{hr}$. at $60^{\circ} \mathrm{C}$. After $1 \mathrm{~h}$. these solutions were injected under optimized chromatographic conditions.

\section{Alkaline hydrolysis}

For alkali degradation, $1 \mathrm{ml}$ of $0.1 \mathrm{M}$, $0.5 \mathrm{M}, 1 \mathrm{M}$ and $2 \mathrm{M} \mathrm{NaOH}$ were added individually to final drug solution in different volumetric flasks and they were refluxed for $1 \mathrm{hr}$. at $60^{\circ} \mathrm{C}$. After $1 \mathrm{hr}$. these solutions were injected under optimized chromatographic conditions.

\section{Oxidative degradation}

For oxidative degradation, $1 \mathrm{ml}$ of $1 \%$, $3 \%, 5 \%$ and $10 \% \mathrm{H}_{2} \mathrm{O}_{2}$ were added individually to final drug solution in different volumetric flasks and they were refluxed for $1 \mathrm{~h}$. at $60^{\circ} \mathrm{C}$. After $1 \mathrm{~h}$. these solutions were injected under optimized chromatographic conditions.

Note: The acidic and basic solutions were neutralized with respective solutions (with base for acidic solutions; with acid for basic solutions) before dilution.

\section{Photolytic degradation}

For photolytic degradation, the final drug solution was exposed to sun light for $8 \mathrm{hrs}$. After $8 \mathrm{~h}$, this solution was injected under optimized chromatographic conditions.

\section{Thermal degradation}

For thermal degradation, the final drug solution was kept at a temperature of $105^{\circ} \mathrm{C}$ for 6 hours. After $6 \mathrm{hr}$. this solution was injected under optimized chromatographic conditions.

\section{Neutral hydrolysis}

For neutral hydrolysis, the final drug concentration is refluxed for $1 \mathrm{hr}$. at $60^{\circ} \mathrm{C}$. After $1 \mathrm{hr}$. this solution was injected under optimized chromatographic conditions.

The stress degradation study was conducted on $1^{\text {st }}$ day, $3^{\text {rd }}$ day and $5^{\text {th }}$ day for the above mentioned solutions and the degradation was studied.

\section{Method validation \\ Linearity}

The linearity of analytical method is its ability to elicit test results that are directly proportional to the concentration of analyte in sample within a given range.

\section{HPTLC}

From the standard stock solution, working linearity range solutions of range $10 \mu \mathrm{g} / \mathrm{ml}$ to $60 \mu \mathrm{g} /$ $\mathrm{ml}$ for MOX and $100 \mu \mathrm{g} / \mathrm{ml}$ to $600 \mu \mathrm{g} / \mathrm{ml}$ for DEX are prepared. $10 \mu$ l solutions are spotted on TLC plate to obtain final concentration of 100-600 ng/spot for MOX and $1000-6000 \mathrm{ng} / \mathrm{sp}$ ot for DEX. Each concentration was applied six times to the TLC plate. The plate was then developed as per the procedure.

\section{HPLC}

From the standard stock solution, working linearity range solutions for RP-HPLC method were fixed as $5-60 \mu \mathrm{g} / \mathrm{ml}$ and $1-12 \mu \mathrm{g} / \mathrm{ml}$ for MOX and DEX respectively are prepared. Twenty microliters of the prepared solutions were injected in triplicate. Linearity was evaluated by regression analysis, which was calculated by the least square regression method.

\section{Accuracy}

Accuracy may often be expressed as percentage recovery. Accuracy of the method was carried by applying the method to drug sample to which known amount of MOX and DEX standard drug powder corresponding to 80, 100 and $120 \%$ of label claim had been added for HPTLC method. $50 \%, 100 \%$ and $150 \%$ were selected as accuracy levels for HPLC method. The respective solutions were mixed and analyzed by running chromatogram in optimized mobile phase. 


\section{Precision}

The precision of an analytical procedure expresses the closeness of measurements obtained from multiple sampling of the same homogenous sample under the prescribed conditions. Precision may be considered at three levels: repeatability, intermediate precision and

Table 1: RP-HPLC System suitability parameters

\begin{tabular}{lcc}
\hline Parameter & \multicolumn{2}{c}{ Observation* $^{*}$} \\
& MOX & DEX \\
\hline Retention time(min) & 2.144 & 4.737 \\
No. of Theoretical plates & 4029 & 10942 \\
Tailing Factor & 1.03 & 1.10 \\
\hline
\end{tabular}

${ }^{*}$ Average of six readings reproducibility. The precision of an analytical procedure is usually expressed as the variance, standard deviation or coefficient of variation of a series of measurements.

HPTLC

Repeatability studies were performed by analysis of $300 \mathrm{ng} / \mathrm{spot}$ for MOX and $3000 \mathrm{ng} / \mathrm{spot}$ for DEX of the drugs six times in three different times on the same day. The intermediate precision of the method was checked by repeating the studies on three different days.

HPLC

Precision of RP-HPLC method were checked by analyzing the samples at different levels (50\%, 100\% and $150 \%)$ at three different time intervals of the same day (intra-day precision) as well as on different days (inter-day precision).

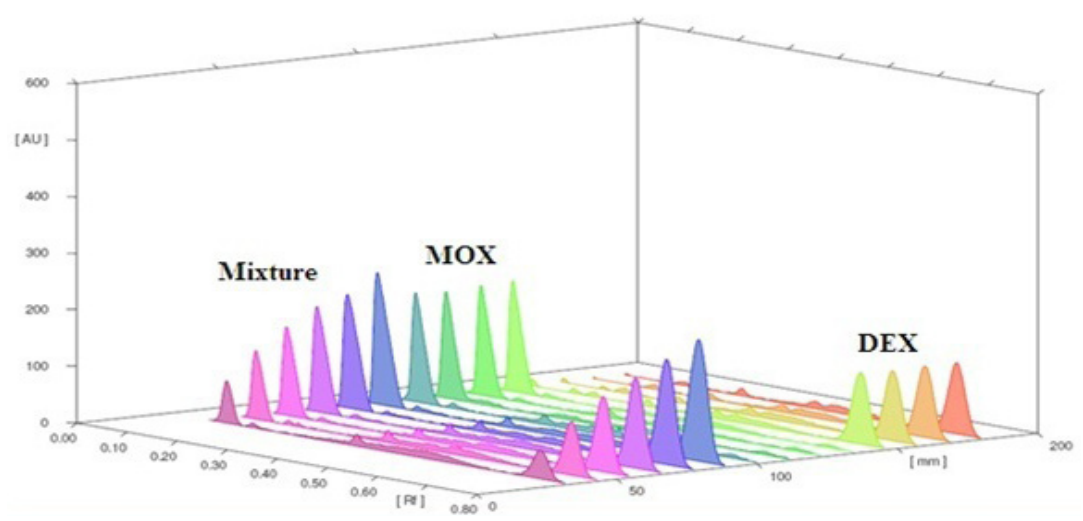

Fig. 7: HPTLC Chromatogram plots showing linearity

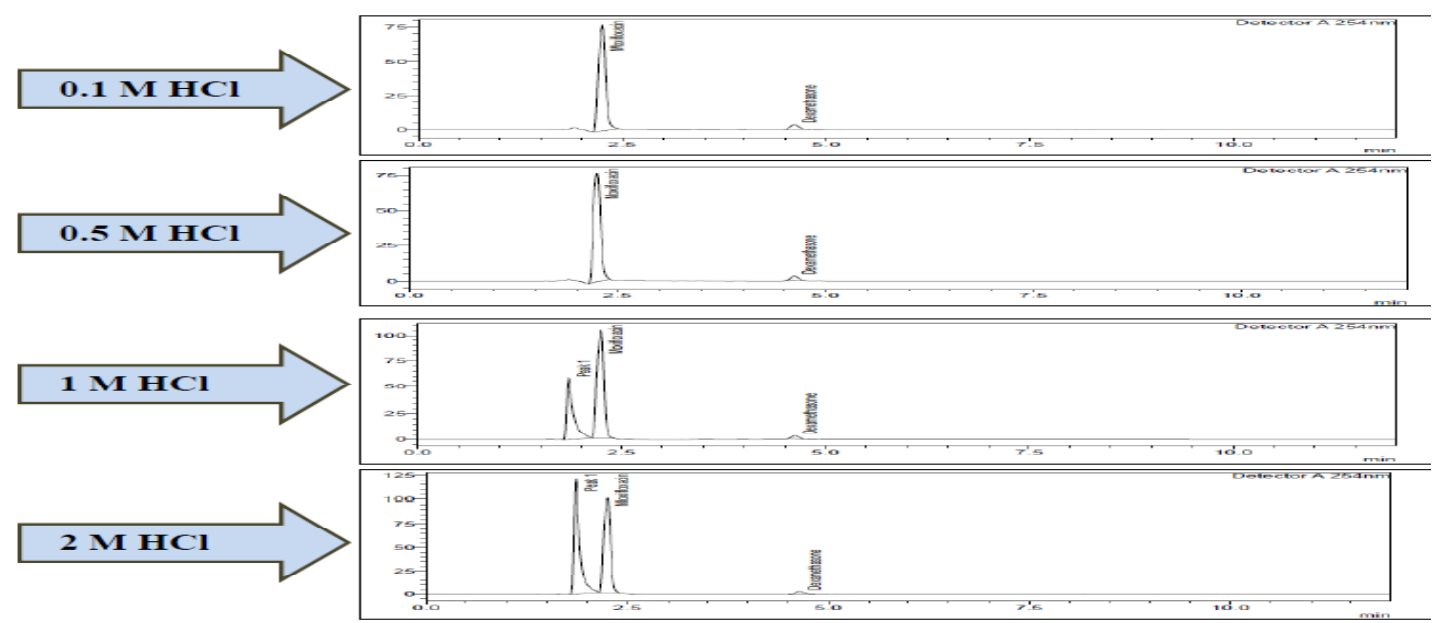

Fig. 8: Chromatogram of MOX and DEX in acidic stress condition 
Table 2: Linearity values of MOX and DEX

\begin{tabular}{llll}
\hline Method & Parameter & MOX & DEX \\
& & & \\
\hline \multirow{2}{*}{ HPTLC } & Regression equation & $\mathrm{Y}=7.672 \mathrm{X}+464.1$ & $\mathrm{Y}=935.5 \mathrm{X}+346.4$ \\
& Linearity & $100-600 \mathrm{ng} / \mathrm{spot}$ & $1000-6000 \mathrm{ng} / \mathrm{spot}$ \\
& Correlation coefficient & 0.993 & 0.997 \\
\multirow{2}{*}{ HPLC } & Regression equation & $\mathrm{Y}=20594 \mathrm{X}+18057$ & $\mathrm{Y}=5193 \mathrm{X}+1005$ \\
& Linearity & $5-60 \mu \mathrm{g} / \mathrm{ml}$ & $1-12 \mu \mathrm{g} / \mathrm{ml}$ \\
& Correlation coefficient & 0.998 & 0.998 \\
\hline
\end{tabular}

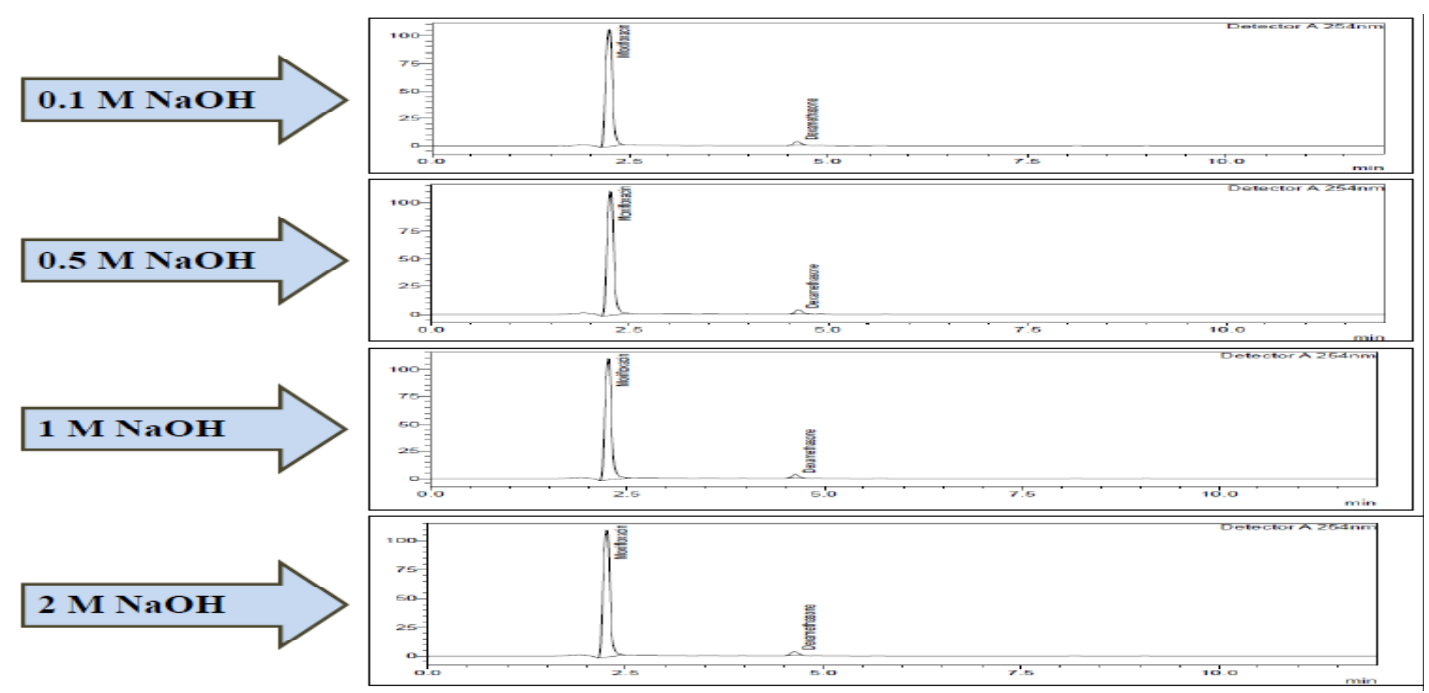

Fig. 9: Chromatogram of MOX and DEX in alkali stress condition

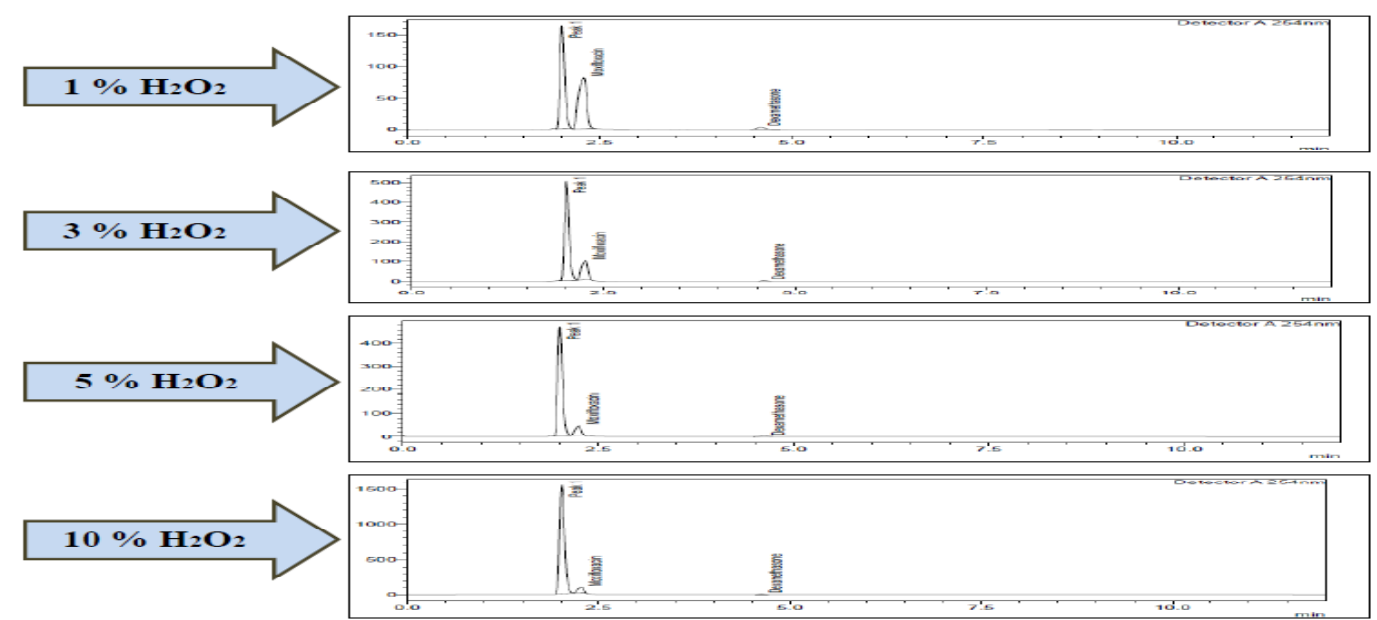

Fig. 10: Chromatogram of MOX and DEX in peroxide stress condition 


\section{Ruggedness}

The ruggedness of an analytical method is determined by analysis of aliquots from homogenous lots by different analysts using operational and environmental conditions that may differ but are still within the specified parameters of the assay. The assay was performed in different conditions, different analysts and on different dates.

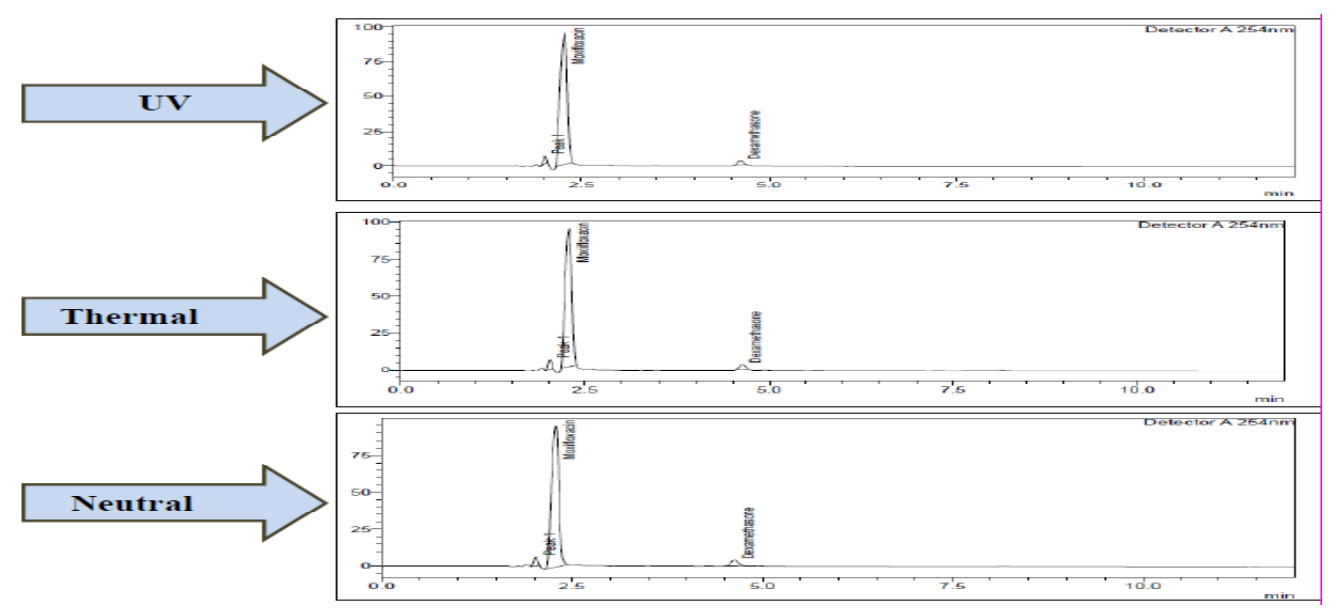

Fig. 11: Chromatogram of MOX and DEX in other stress conditions

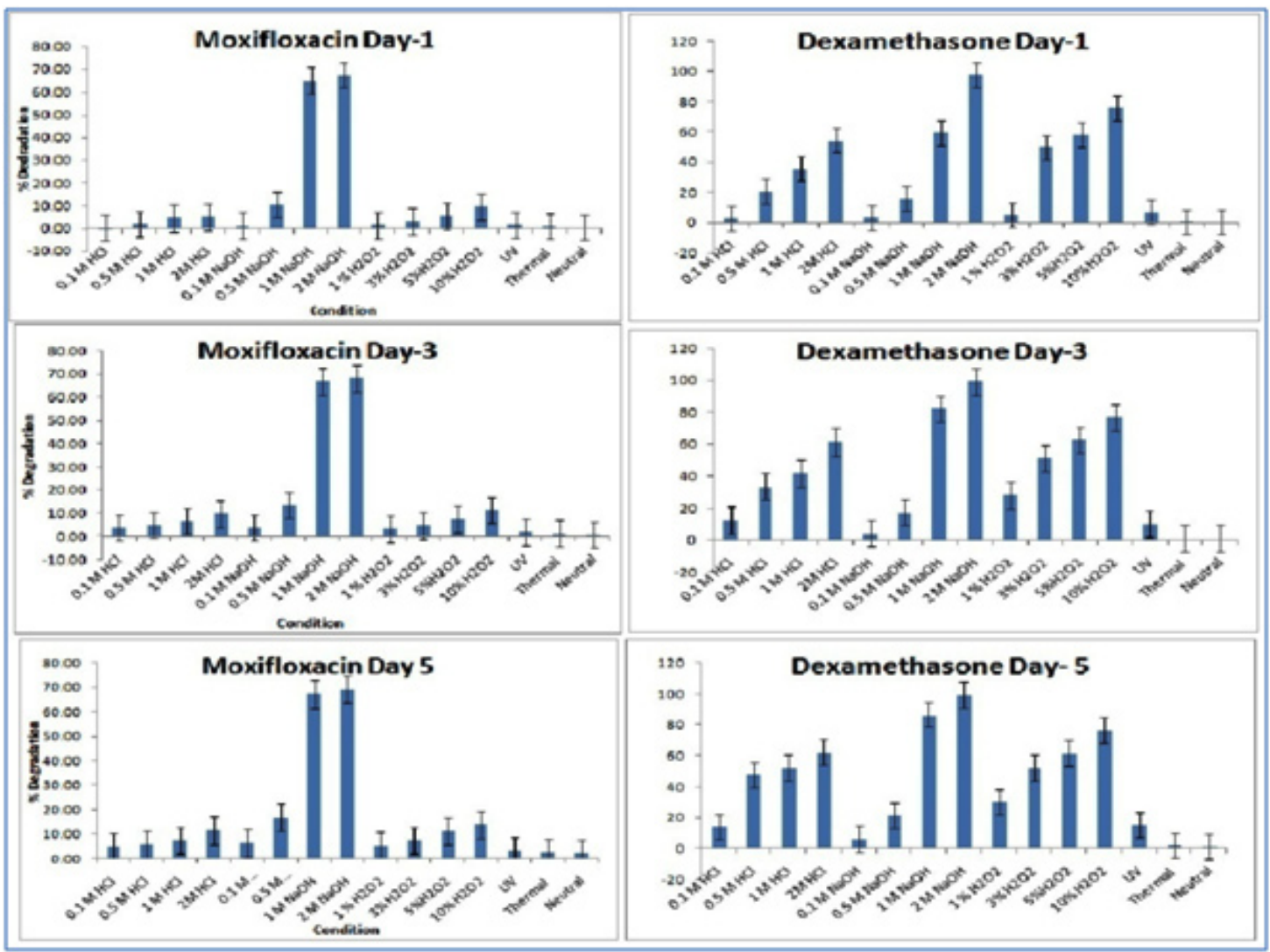

Fig. 12: Graphs showing degradation pattern of MOX and DEX in different conditions 


\section{Robustness}

The robustness was studied by evaluating the effect of small but deliberate changes in chromatographic conditions.

\section{HPTLC}

Change in mobile phase composition, e.g. acetonitrile:water: ammonia (8.1:1:0.5 V/V/V), (7.9:1:0.5 V/V/V), (8:1.1:0.5 V/V/V), (8:0.9:0.5 V/V/V) were tried and chromatograms were studied. The amount of mobile phase varied over the range of $\pm 5 \%$, the time from spotting to chromatography and from chromatography to scanning was varied by $+/-10$ minutes.

\section{HPLC}

The flow rate of the mobile phase was changed from $1.1 \mathrm{ml} / \mathrm{min}$ to $1.2 \mathrm{ml} / \mathrm{min}$ and $1.3 \mathrm{ml} /$ $\min$. The ratio of the organic phase was changed by $\pm 5 \%$, i.e., $35 \%, 40 \%, 45 \%$ of acetonitrile. The $\mathrm{pH}$ of the mobile phase was changed as 3.5, 4.0 and 4.5. The effect on retention time and peak parameter were studied.

\section{Limit of detection (LOD)}

The limit of detection (LOD) is the smallest concentration that can be detected but not necessarily quantified as an exact value. LOD is calculated from the formula; $L O D=3.3 \delta / S$

Where, $\delta=$ standard deviation of the response, $\mathrm{S}=$ slope of calibration curve

\section{Limit of quantitation (LOQ)}

The limit of quantitation (LOQ) is the lowest amount of analyte in the sample that can be quantitatively determined with precision and accuracy. $L O Q$ is calculated from formula;

$$
\mathrm{LOQ}=10 \delta / \mathrm{S}
$$

Where, $\delta=$ standard deviation of the response, $\mathrm{S}=$ slope of calibration curve.

Table 3: Precision values of MOX and DEX

\begin{tabular}{cccccc}
\hline Method & Drug & $\begin{array}{c}\text { Concentration } \\
(\boldsymbol{\mu} \mathbf{g} / \mathrm{ml})\end{array}$ & $\begin{array}{c}\text { Intra-day } \\
(\% \text { RSD })\end{array}$ & $\begin{array}{c}\text { Inter-day } \\
(\% \text { RSD })\end{array}$ & $\begin{array}{c}\text { System precision } \\
(\% \text { RSD })\end{array}$ \\
\hline \multirow{2}{*}{ HPTLC } & MOX & $300 \mathrm{ng} / \mathrm{spot}^{\star}$ & 1.05 & 0.64 & 1.50 \\
& DEX & $3000 \mathrm{ng} / \mathrm{spot}^{\star}$ & 0.99 & 1.16 & 0.84 \\
HPLC & MOX & 12.5 & 1.26 & 1.50 & 1.12 \\
& & 25 & 0.07 & 1.14 & \\
& & 37.5 & 1.56 & 0.10 & 0.41 \\
& DEX & 2.5 & 1.28 & 0.51 & \\
& & 5 & 0.24 & 0.07 & \\
\hline
\end{tabular}

${ }^{*}$ Average of Six readings

Table 4: Recovery values of MOX and DEX

\begin{tabular}{ccccccc}
\hline Drug & \multicolumn{5}{c}{$\begin{array}{c}\text { HPTLC method } \\
\text { Recovery }\end{array}$} & \% RSD \\
\hline & $80 \%$ & $100 \%$ & $120 \%$ & $80 \%$ & $100 \%$ & $120 \%$ \\
MOX & 98.08 & 99.07 & 99.03 & 1.14 & 0.07 & 0.10 \\
DEX & 98.16 & 100.57 & 99.78 & 1.28 & 0.51 & 0.24 \\
\multicolumn{7}{c}{ HPLC method } \\
Recovery & $\%$ RSD \\
Drug & $50 \%$ & $100 \%$ & $150 \%$ & $50 \%$ & $100 \%$ & $150 \%$ \\
MOX & 99.21 & 100.56 & 98.90 & 0.35 & 0.60 & 0.67 \\
DEX & 98.54 & 100.40 & 100.15 & 0.16 & 0.55 & 0.80 \\
\hline
\end{tabular}


Specificity

Specificity of the method was determined by means of complete separation of pure drugs in the presence of other excipients normally present in the formulation.
HPTLC

The specificity of the method was ascertained by peak purity profiling studies. Peak purity of MOX and DEX were assessed by comparing their respective spectrum at peak start (S), peak

Table 5a: Robustness parameters of MOX and DEX by HPTLC

\begin{tabular}{lcccc}
\hline Parameter & $\begin{array}{c}\text { MOX } \\
\text { Peak area } \\
\text { (S.D) }\end{array}$ & $\begin{array}{c}\text { DEX } \\
\text { Peak area } \\
\text { (S.D) }\end{array}$ & $\begin{array}{c}\text { MOX } \\
\% \text { RSD }\end{array}$ & $\begin{array}{c}\text { DEX } \\
\% \text { RSD }\end{array}$ \\
\hline Mobile phase composition $( \pm 0.1 \mathrm{ml})$ & 27.39 & 34.28 & 0.88 & 1.11 \\
Amount of mobile phase $( \pm 0.5 \mathrm{ml})$ & 37.85 & 31.58 & 1.22 & 1.02 \\
Time from application to development $(+10 \mathrm{~min})$ & 22.00 & 22.39 & 0.83 & 0.66 \\
Time from development to scanning $(+10 \mathrm{~min})$ & 2.49 & 38.85 & 0.08 & 1.15 \\
\hline
\end{tabular}

Table 5b: Robustness parameters of MOX \& DEX by RP-HPLC

\begin{tabular}{lcc}
\hline Parameter & $\begin{array}{c}\text { MOX } \\
\text { Rt (min) }\end{array}$ & $\begin{array}{c}\text { DEX } \\
\text { Rt (min) }\end{array}$ \\
\hline Initial Flow & 2.14 & 4.73 \\
Flow $1.1 \mathrm{ml} / \mathrm{min}$ & 2.41 & 5.12 \\
Flow $1.3 \mathrm{ml} / \mathrm{min}$ & 2.04 & 4.28 \\
Organic phase, & 2.43 & 6.45 \\
$10 \%$ more (35 \%) & & \\
Organic phase, & 2.09 & 3.73 \\
10\% less (45 \%) & & \\
pH 3.5 & 2.18 & 4.64 \\
pH 4.5 & 2.24 & 4.65 \\
\hline
\end{tabular}

Table 6: LOD and LOQ of MOX and DEX

\begin{tabular}{lccc}
\hline Method & Drug & LOD & LOQ \\
\hline HPTLC & MOX & $8.572 \mathrm{ng} / \mathrm{ml}$ & $25.97 \mathrm{ng} / \mathrm{ml}$ \\
& DEX & $0.137 \mu \mathrm{gl}$ & $0.417 \mu \mathrm{m} / \mathrm{ml}$ \\
HPLC & MOX & $1.09 \mu \mathrm{g} / \mathrm{ml}$ & $3.29 \mu \mathrm{g} / \mathrm{ml}$ \\
& DEX & $0.22 \mu \mathrm{g} / \mathrm{ml}$ & $0.67 \mu \mathrm{g} / \mathrm{ml}$
\end{tabular}

apex (M) and peak end (E) position of the spots. The specificity was noticed by the complete separation of MOX and DEX peaks. The peak purity was assessed by comparing their respective spectra at the peak start, apex and peak end positions of the spot.

\section{HPLC}

A study to establish the interference of blank and placebo were conducted. Diluent and placebo were injected into the chromatograph in the above chromatographic conditions and the blank and placebo chromatograms were recorded.

\section{Assay of marketed formulation HPTLC}

Five different batches of marketed formulations were tried for this purpose. To determine the content of MOX and DEX in the eye drops (Moxi Mep D), which contains $5 \mathrm{mg}$ of MOX and $1 \mathrm{mg}$ of DEX per $\mathrm{ml}, 3 \mathrm{ml}$ of formulation i.e., eye drops were carefully with drawn and transferred in to a clean and dry $10 \mathrm{ml}$ volumetric flask. The volume was made upto the mark using methanol:water $(50: 50 \mathrm{~V} / \mathrm{V})$ as

Table 7: Assay data of marketed formulation

\begin{tabular}{cccccc}
\hline \multirow{2}{*}{ Method } & Drug & Amount labeled & Amount found & \%Label claim & \% RSD \\
\hline \multirow{2}{*}{ HPTLC } & MOX & $5 \mathrm{mg} / \mathrm{ml}$ & 4.98 & 99.60 & 0.54 \\
& DEX & $1 \mathrm{mg} / \mathrm{ml}$ & 1.01 & 101.00 & 1.77 \\
\multirow{2}{*}{ HPLC } & MOX & $5 \mathrm{mg} / \mathrm{ml}$ & 4.99 & 99.80 & 0.15 \\
& DEX & $1 \mathrm{mg} / \mathrm{ml}$ & 0.99 & 99.00 & 0.96 \\
\hline
\end{tabular}


solvent. The prepared solution contains $1500 \mu \mathrm{g} / \mathrm{ml}$ of MOX and $300 \mu \mathrm{g} / \mathrm{ml}$ of DEX.

\section{For the assay of DEX}

$10 \mu \mathrm{l}$ of the above solution is applied as band which contains $15 \mu \mathrm{g} / \mathrm{spot}$ of MOX and 3000 $\mathrm{ng} / \mathrm{spot}$ of DEX.

\section{For the assay of MOX}

$1 \mathrm{ml}$ of the above solution is diluted to $50 \mathrm{ml}$ solvent to get $30 \mu \mathrm{g} / \mathrm{ml}$ of MOX and $6 \mu \mathrm{g} / \mathrm{ml}$ of DEX. Ten micro liters of this solution is applied which contains $300 \mathrm{ng} / \mathrm{spot}$ of MOX and $60 \mathrm{ng} / \mathrm{spot}$ of DEX.

In order to have the linearity range within Beer-Lambert's law limits, the above additional step is taken as the UV absorption of MOX is very high when compared to DEX.

\section{HPLC}

Five different batches of marketed formulations were tried for this purpose. To determine the content of MOX and DEX in the eye drops (Moxi Mep D), which contains $5 \mathrm{mg}$ of MOX and $1 \mathrm{mg}$ of DEX per $\mathrm{ml}, 1 \mathrm{ml}$ of formulation i.e., eye drops were carefully with drawn and transferred in to a clean and dry $100 \mathrm{ml}$ volumetric flask. The volume was made upto the mark using acetonitrile:water (50:50 $\mathrm{v} / \mathrm{v}$ ) as solvent. The prepared solution contains 50 $\mu \mathrm{g} / \mathrm{ml}$ of MOX and $10 \mu \mathrm{g} / \mathrm{ml}$ of DEX. Five $\mathrm{ml}$ of the above solution was pipette and transferred into 10 $\mathrm{ml}$ volumetric flask and diluted to mark with mobile phase to obtain a final concentration of $25 \mu \mathrm{g} / \mathrm{ml}$ of MOX and $5 \mu \mathrm{g} / \mathrm{ml}$ of DEX.

Table 8 a: Forced Degradation Studies of MOX and DEX

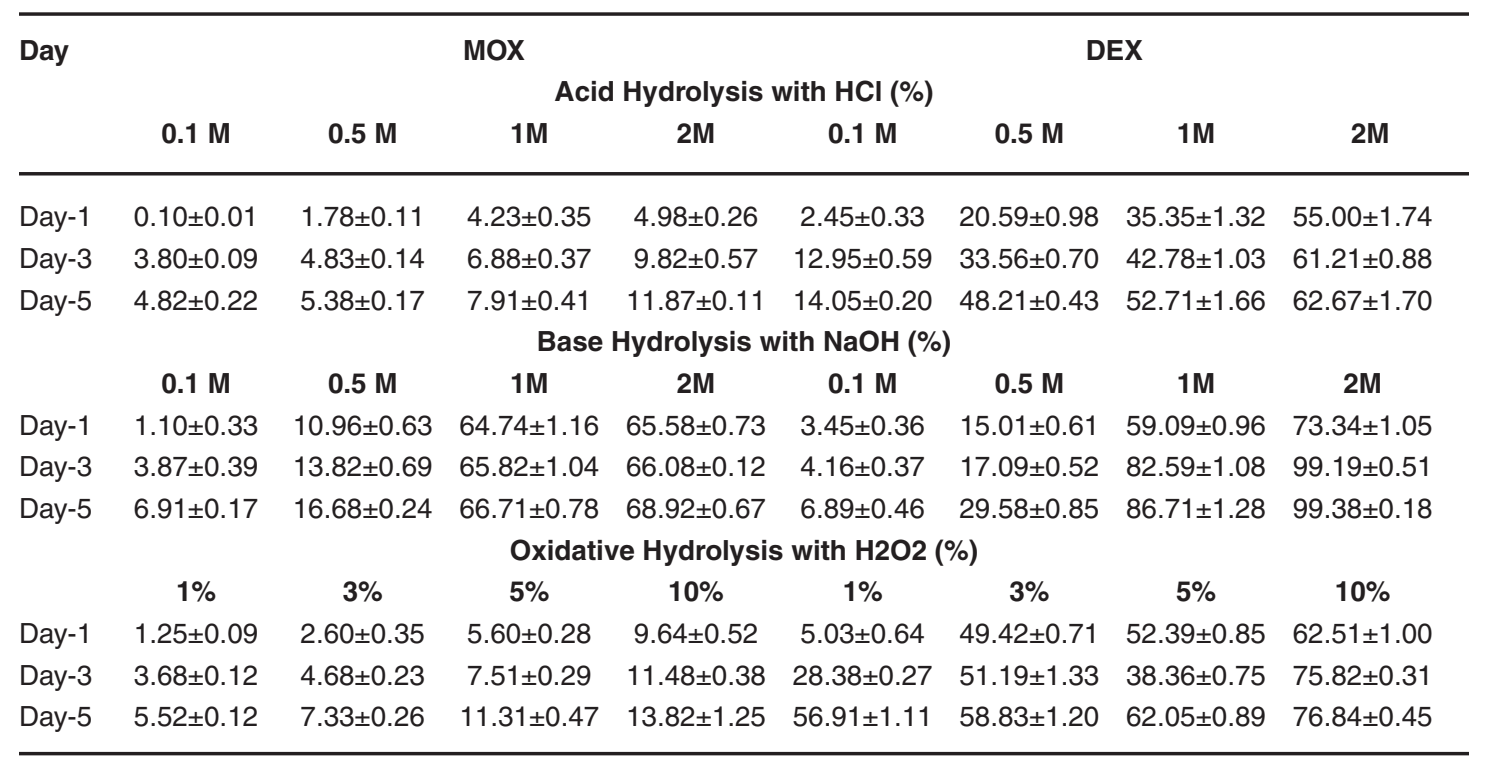

Table 8 b: Forced Degradation studies of MOX and DEX

\begin{tabular}{ccccccc}
\hline \multicolumn{7}{c}{ Oother Hydrolysis Methods (\%) } \\
& UV & Thermal & Neutral & UV & Thermal & Neutral \\
& & & & & & \\
\hline Day-1 & $1.45 \pm 0.48$ & $1.49 \pm 0.17$ & $0.39 \pm 0.03$ & $6.94 \pm 0.13$ & $0.59 \pm 0.10$ & $0.29 \pm 0.38$ \\
Day-3 & $2.52 \pm 0.16$ & $1.68 \pm 0.38$ & $1.82 \pm 0.11$ & $9.79 \pm 0.42$ & $0.79 \pm 0.18$ & $0.73 \pm 0.21$ \\
Day-5 & $3.09 \pm 0.43$ & $2.21 \pm 0.25$ & $1.37 \pm 0.62$ & $15.14 \pm 0.61$ & $1.92 \pm 0.37$ & $1.41 \pm 0.22$ \\
\hline
\end{tabular}

*Average of three determinations (each condition), DEG: Degradation, SD: Standard deviation 


\section{RESULTS AND DISCUSSION}

\section{HPTLC method}

The proposed HPTLC method, allows a rapid and accurate quantitation of MOX and DEX in ophthalmic preparation. The response of the drugs is linear $\left(r^{2}=0.993\right.$ for MOX and 0.997 for DEX) over the concentration range of $100-600 \mathrm{ng} / \mathrm{spot}$ for MOX and $1000-6000 \mathrm{ng} / \mathrm{sppot}$ for DEX. The linearity values were tabulated in Table 2. The results of repeatability and intermediate precision were shown in Table 3. The developed method was found to be precise as the RSD values for both the drugs were $<2 \%$ respectively as recommended by $\mathrm{ICH}$ guidelines. As shown in Table 4, the values showed good recoveries for both the drugs in the range of $98.03-99.07 \%$ for MOX and $98.16-100.57 \%$ for DEX respectively. The specificity studies of drugs were shown in Fig. 6.

The standard deviation of the peak areas was calculated for each deliberate change made and the RSD values were found to be less than $2 \%$. The values were shown in Table $5 a$ \& Table $5 b$, indicated the method is robust. The LOD and LOQ were calculated using the values of slopes and intercepts of the calibration curves for both the drugs (Table 6). The experiments performed by different analysts showed the RSD values less than $2 \%$. This indicates the method is rugged. The peak purity of MOX and DEX was determined by comparing their spectra at peak start, apex and at end positions which are with in the limits. A good correlation $\left(r^{2}=0.997\right)$ was obtained between the spectra of MOX and DEX sample and standard without any interferences. The digital response chromatograms were shown in Fig. 7. Experimental results show that the amount of MOX and DEX in eye drops was in good agreement with the labeled claim suggesting no interferences from other excepients. The drug content was found to be $99.60 \%$ for MOX and $101.00 \%$ for DEX respectively. The values were shown in Table 7 .

\section{HPLC method}

Different proportions of acetonitrile and acetate buffer were tried for selection of mobile phase. Ultimately, $0.02 \mathrm{M}$ acetate buffer $(\mathrm{pH}$ is 4 adjusted with triethylamine) and acetonitrile in the ratio of 60:40 V/V. Typical chromatogram obtained from the analysis of standard solution of MOX and
DEX using the proposed method was shown in Fig. 5. The elution order was MOX ( $\mathrm{Rt}=2.144 \mathrm{~min})$ and DEX (Rt=4.732 $\mathrm{min}$ ), at a flow rate of $1.2 \mathrm{ml} / \mathrm{min}$. The chromatogram was recorded at $254 \mathrm{~nm}$.

The calibration curves for MOX and DEX were constructed in the concentration range of $5-60 \mu \mathrm{g} / \mathrm{ml}$ and $1-12 \mu \mathrm{g} / \mathrm{ml}$ for MOX and DEX respectively and the correlation coefficient for both the drugs was found to be nearer to 1. Precision was calculated as inter-day and intra-day variations for both the drugs. Percent relative standard deviations for estimation of MOX and DEX under intra-day and inter-day variations were found to be less than 2. The accuracy of proposed method was determined, indicating an agreement between the true value and found value. The LOD and LOQ were calculated using the values of slopes and intercepts of the calibration curves for both the drugs and for robustness studies in all deliberately varied conditions, percent relative standard deviations were found to be less than $2 \%$. The experimental values obtained for the determination of MOX and DEX in ophthalmic formulation was within the claimed limits. Chromatograms of blank and placebo showed no peaks at the retention times of MOX and DEX peaks. This indicates that the diluent and placebo used in the sample preparation did not interfere in simultaneous estimation of MOX and DEX and hence the method is specific.

\section{Stress degradation conditions}

The following degradation results were found when MOX and DEX were subjected to,

\section{Acid hydrolysis}

MOX showed good stability in acidic conditions compared to DEX. MOX was stable in almost all acidic conditions. It showed appreciable degradation in $2 \mathrm{M} \mathrm{HCl}$. DEX show stability in $0.1 \mathrm{M} \mathrm{HCl}$, but degraded in other acidic conditions (Fig. 8).

\section{Alkaline hydrolysis \\ MOX showed stability in $0.1 \mathrm{M} \mathrm{NaOH}$. But, the \% degradation increased in $0.5 \mathrm{M} \mathrm{NaOH}$, $1 \mathrm{M} \mathrm{NaOH}$ and $2 \mathrm{M} \mathrm{NaOH}$. Whereas, DEX showed stability in $0.1 \mathrm{M} \mathrm{NaOH}$ with degradation in other basic conditions (Fig. 9).}




\section{Oxidative degradation}

MOX showed good stability in peroxide conditions compared to DEX. MOX was stable in $1 \%, 3 \%$ and $5 \% \mathrm{H}_{2} \mathrm{O}_{2}$. It showed appreciable degradation in $10 \% \mathrm{H}_{2} \mathrm{O}_{2}$. DEX showed degradation in all peroxide conditions (Fig. 10).

\section{Photolytic degradation}

Both the drugs showed good stability under photolytic conditions with very less degradation. DEX showed more degradation in $3^{\text {rd }} \& 5^{\text {th }}$ day compared to MOX (Fig. 11).

\section{Thermal hydrolysis}

Both the drugs showed good stability under thermal conditions with very less degradation (Fig. 11).

\section{Neutral hydrolysis}

Both the drugs showed good stability under neutral conditions with very less degradation (Fig. 11).

The percent amount of drug degraded after degradation studies were given in Table 8a \& Table 8b. The pattern of degradation of the drugs individually in different conditions was well portrayed in the Fig. 12.

\section{CONCLUSION}

The developed HPTLC and stability indicating RP-HPLC methods were validated as per $\mathrm{ICH}$ guidelines. The standard deviation and $\%$ RSD calculated for the proposed methods are low, indicating high degree of precision of the methods. The results of the recovery studies performed show the high degree of accuracy for the proposed methods. The RP-HPLC method could selectively quantitate MOX and DEX in presence of its degradation products hence, it can be employed as a stability indicating method. From the found experimental data it can be concluded that the developed HPTLC and stability indicating chromatographic methods are accurate, precise and selective and can be employed successfully for the estimation of MOX and DEX in ophthalmic dosage form.

\section{ACKNOWLEDGEMENTS}

The authors would like to thank Anchrom Labs, Mumbai and Sri Vasavi Institute of Pharmaceutical Sciences, Tadepalligudem for providing necessary facilities to carry out the research work.

\section{REFERENCES}

1. Data base of Moxifloxacin $\mathrm{HCl}$, compilation prepared by drug bank, http://www.drugbank. ca/drugs/DB00218

2. Data base of Dexamethasone, compilation prepared by drug bank,http://www.rxlist.com/ dexamethasone-drug.htm

3. Data base of Dexamethasone, compilation prepared by Rx List,http://www.drugbank.ca/ drugs/DB01234

4. Renuka, D.N.; Prathyusha, V. Indo Amer. J. Pharm. Res., 2013, 3(7), 5055-5061.

5. Singh, D.K.; Verma, R. Iran. J. Pharm. Ther., 2008, 7, 61-65.

6. Chothani, D.; Bhalani, J.; Vadaliya, K.R. Inventi Rapid: Pharm Analysis \& Quality Assurance, 2013, 2, 1-5.

7. Bhalani, J.; Vadalia, K.; Dedania, Z.R. Inventi Rapid: Pharm Analysis \& Quality Assurance, 2012, 1, 1-5.
8. Dhumal, D.M.; Shirkhedkar, A.A.; Surana, S.J. Anal. Chem. Ind. J., 2013, 12(3), 15-17.

9. Sireesha, K.; Prakash, K. Int. J. Pharm. Pharm. Sci., 2012, 4, 415-418.

10. Dabhi, M. J. J. Chem. Pharm. Res., 2012, 4, 4462-4467.

11. Prakash, K.; Sireesha, K.R. Eur. J. Anal. Chem., 2012, 7(2), 89-95.

12. Shadoul, W.A.; Gad Kariem, E.A.; Adam, M.E.; Ibrahim, K.E. Int. J. Chem. Sci. Tech., 2011, 1, 60-69.

13. Prakash, K.; Sireesha, K.R.; Shantha K.A. Int J. Pharm. Pharm. Sci., 2012, 4, 505-510.

14. Prakash, K.; Sireesha, K.R. J. Chem., 2012, 9, 1077-1084.

15. Razzaq, S.N.; Ashfaq, M.; Khan, I.U.; Mariam, I.; Razzaq, S.S.; Azeem, W. Arab. J. Chem., 2014. In Press.

16. Raja, B.; Rao, L.A. Int. J. Pharm., 2013, 3, 
621-627.

17. Kumar, J.K.M.; Bhanubhai, N.S.; Rathod, S.I. World J. Pharm. Pharm. Sci., 2013, 2, 593600.

18. Seid, Y.; Hymete, A.; Bekhit, A.A. Thai J. Pharm. Sci., 2012, 36, 94-99.

19. Vandana, V; Chaudhary, A.K. African J. Pharm. Sci. Pharm., 2010, 1, 74.
20. ICH Harmonized Tripartite Guideline, Q2(R1). Validation of analytical procedures: text and methodology. International Conference on Harmonization, Geneva. 2005, 1-13.

21. ICH Harmonized Tripartite Guideline, Q1A. Guidance on stability testing: stability testing of new drug substances and new drug products. International Conference on Harmonization, Geneva. 2003, 1-10. 